\title{
Factors Influencing the Sustainability of Social Enterprises in Korea: Application of the QCA Method
}

\author{
Young-Chool Choi ${ }^{1}$ and Ji-Hyun Jang ${ }^{2}$ \\ ${ }^{1}$ Department of Public Administration, Chungbuk National University, Korea \\ ${ }^{2}$ College of Liberal Arts, Sangmyung University, Korea \\ lycchoi@cbu.ac.kr
}

\begin{abstract}
The unemployment rate is not improving in Korea, income disparity between the rich and the poor is growing, and a high percentage of young university graduates have no jobs (the employment rate is approximately 58\% as of 2014). Demands by ordinary people for employment and for more social welfare are getting strong and serious. Against this background, social enterprises in Korea began as a means of solving the problem of unemployment among vulnerable social groups, in particular and expanding the supply of social services. Since 2007 when The Social Enterprise Promotion Act that was established, the number of social enterprises has been constantly increasing at a slow but steady rate, and as of December 2014 there were 1251 in total. However, criticisms have been made as to the sustainability of social enterprises for failing to continue operation, or reducing in size once the benefits and government aid they receive as certified enterprises come to an end. This paper aims to investigate the factors influencing the sustainability of social enterprises in Korea, and to put forward theoretical and policy implications on how to enhance the sustainability of social enterprises.
\end{abstract}

Keywords: social enterprise, sustainability of social enterprise, social economy, social enterprise in Korea, QCA

\section{Introduction}

As the OECD Research Report [1] mentions, there is no commonly accepted definition of the term 'social enterprise'. This is because most countries develop various statutory and non-statutory institutions to support those experiencing disadvantages caused by the gap between market economy and national welfare. Nevertheless, one common characteristic countries share is that a social enterprise belongs to a so-called social economy organization, and is widely perceived as an organizational form that aims to accomplish both social goals and enterprise goals [2]. As will be mentioned later, a social enterprise is situated between a commercial enterprise and a non-profit enterprise, and means an enterprise (organization) that performs business activities such as production and sales while primarily focusing on fulfilling social goals. The Social Enterprise Promotion Act that was established in 2007 in Korea defines a social enterprise as 'an organization certified by the Minister of Employment and Labor which performs business activities such as production and sales while providing social service or employment to socially vulnerable social groups'. The number of social enterprises has been constantly increasing at a slow but steady rate, and as of December 2014 there were 1251 in total. However, criticisms have been made as to the sustainability of social enterprises for failing to continue operation, or reducing in size once the benefits and government aid they receive as certified enterprises come to an end. This phenomenon is not only restricted to Korea, but appears in more advanced countries that have a deeper history of social enterprises. In this connection, OECD launched the Local Economic and Employment Development (LEED) program, and is continuing focused research on the 
sustainability of social enterprises and the social economy. Against such a background, the objective of this research is to investigate the factors influencing the sustainability of social enterprises in Korea. Social enterprises in Korea exhibit apparent similarities and differences in their legal nature and management to foreign ones, and for this reason, previous research from countries with a deeper historical background of social enterprises will also be examined. In particular, contemporary research both inside and outside Korea aimed at discovering the factors influencing the sustainability of social enterprises relied on literature studies, case studies, or surveys on a normative dimension. However, though it is limited to certain areas, in this research, data on social enterprises currently under management will be utilized, and on this basis a Qualitative Comparative Analysis (QCA) will be conducted. This will provide theoretical and policy information on how to enhance the sustainability of social enterprises.

\section{Theoretical Discussion; The Research Question}

\subsection{Significance of the Sustainability of Social Enterprises}

The sustainability of a social enterprise can mean its ability to maintain its initial goals of fulfilling both social and business values on a stable basis. Sustainability problems were not widely discussed either inside or outside Korea when social enterprises were first introduced. During this time, wide-scale discussions took place on the effectiveness and necessity of social enterprises. However, following the emergence of social enterprises that after some time had failed to accomplish their initial social and business objectives, problems regarding the sustainability of social enterprises began to be discussed. Recently, the sustainability problem of social enterprises is being addressed not only in Korea but also in various OECD reports, where improvement factors are identified as important issues and several recommendations are proposed.

\subsection{Social Economy and Social Enterprises}

In order to discuss the factors influencing the sustainability of social enterprises it is important to examine the characteristics of social enterprises and of the social economy. This is because the sustainability of social enterprises is closely related to their characteristics, and because a social enterprise belongs to the area of social economy [2]. Therefore, an examination of the broader term 'social economy' should be conducted prior to situating social enterprises in that area. The term 'social economy' is not new, but has been in regular used for decades. The decline of welfare nations can be considered as a stimulus to the growth and development of a social economy. Other factors, such as changes in the local economy and social exclusion of vulnerable social groups, can also be regarded as having contributed to the development of a social economy [2]. Social economy organizations act to compensate for problems caused by gaps between the market and the nation, and have adapted to field demands by creating new opportunities and environments. There are cases, especially in eastern Europe, where a social economy organization has performed an important role in dealing with complicated problems in the local society arising during the transitional period in eastern Europe in 1989. Nevertheless, as in other countries, social economy organizations face important issues regarding their role and sustainability. From an academic perspective, issues of economy theory such as the role of social economy organizations, the support organizations and environments required for a social economy, and how a social economy can affect not only vulnerable social classes but the whole local society, are gaining in importance.

Considering the important role of social economy, it is important to define clearly what social economy actually is, since this makes it easier to understand its characteristics and status. However, defining social economy has always been controversial, since every country in the world has its own definition [3]. 
To be exact, the term 'social economy' was coined in nineteenth-century France, and the definition of social economy has constantly been developed to reflect various historical dimensions and organizational forms [2]. Efforts to define social economy have developed out of two important approaches. The first is to focus on the legal and institutional forms of social economy and emphasizes organizational aspects such as associations, mutual profit organizations and cooperatives. The second is to focus on common principles that apply to social enterprises, such as the principles of profit distribution.

However, if we take a more practical view of how it is actually managed in the field, social economy may follow the American definition, 'the non-profit sector', or the European definition, 'the third system' or 'social economy' [2]. The Comparative Nonprofit Sector Project carried out at Johns Hopkins University in the USA developed the definition of social economy in line with the non-profit sector, with a focus on voluntary organizations that do not distribute profit. According to this definition, social economy organizations include social clubs, specialist organizations, universities and hospitals. However, this definition is considered too narrow to be accepted in Europe, where different historical traditions and backgrounds exist. Above all, this definition excludes cooperatives, an issue that occasions much controversy in Europe.

In fact, as regards Europe, the term 'third system' was first introduced via a project named 'The Third System and Empowerment' presented in the European Commission in 1997, and later, this term expanded to denote all organizations that restrict profit distribution. This definition makes it possible to distinguish between the American and European terms. According to this definition, social economy accounts for a certain area between market and state, and constitutes the economic area that seeks not only social factors but economic factors as well. Yet not all social economy organizations place a focus on economic activities, and it is important to understand that foundations and other organizations that redistribute resources are also sometimes included. Whatever the case, according to the European definition the term 'social economy' is important, owing to its inclusiveness in embracing new organizational forms such as social enterprises. More important, however, is the fact that terms such as 'the third sector', 'the third system', and 'social economy' are being widely used in different countries without distinction.

In order to provide a clear distinction between social economy and social enterprises, Borzaga and Tortia [4] present a figure based on the European definition of social economy Figure 1.

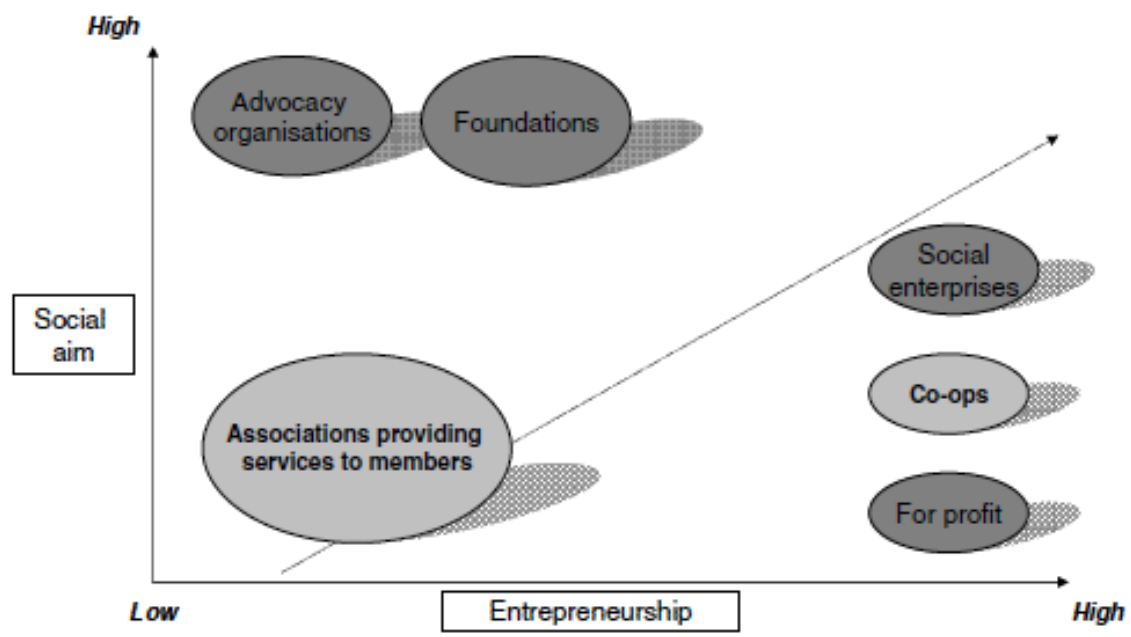

Figure 1. The Social Economy Area and Various Forms of Organization (Source: Borzaga and Tortia 2007: 33) 
As the figure shows, Borzaga and Tortia [4] present standards by dividing organizations according to their desired goals and economic values. This classification enables the positioning of social economy organizations and profit-making organizations. The horizontal axis identifies entrepreneurship and the vertical axis determines whether an organization's goals are high or low in social value. The figure shows that the social economy area comprises several organizational forms, and that a social enterprise is not only high in terms of entrepreneurship but also has goals that are high in social value. That is, a social enterprise is an enterprise that pursues entrepreneurship by being situated between a commercial and nonprofit enterprise, and also performs business activities such as the production and sales of goods and services in order to fulfil social purposes.

The advent and development of social enterprises is closely related to the rapid growth of the social economy sector. The emergence of a social economy sector can be seen generally as a response to demands that cannot be met either by the market or the welfare state. Social economy is seen as a corrective measure against the flaws both of the market (activities should be profitable) and of the welfare state (activities are limited, owing to fiscal restraints). Therefore, social economy is situated where the market, that stimulates economic efficiency, and state intervention, that stimulates social justice, meet, and social enterprises are one of the organizational forms that perform such functions.

\subsection{Factors Influencing the Sustainability of Social Enterprises}

Social enterprises are enterprises that are part of social economy, and this characteristic has led to much discussion from various viewpoints as to their sustainability. This can be categorized as being of various kinds. The first category is that the state should reinforce institutional strategies that support social enterprises. For instance, Hadzi-Miceva [5] and Rutzen et. al., [6] have stated that the primary goal of social economy organizations is to increase sustainability. In this connection, Rutzen et. al., stress the importance of clear and precise supporting rules in order to improve the sustainability of social enterprises, and a legal foundation that regulates organizations from birth to dissolution. The importance of regulations that affect the sustainability of social economy organizations in registration, organizational form, governance and dissolution should not be underestimated. This is because these regulations provide a protective framework for the activities of social economic organizations, and also prevent government intervention in their activities. Meanwhile, although advocates acknowledge the importance of fundamental laws relating to social economic organizations in securing legal status, they also point out that laws should not restrict the unofficial activities of unregistered organizations. Overall, proponents of this view emphasize the importance of legal backgrounds that can ensure the free activity of social economic organizations.

The second viewpoint supports a new business model for the management of social enterprises. Schorr [7] points out the failures of first-generation social enterprises in maintaining sustainability, and argues for a new management model. His so-called 'social enterprise 2.0' criticizes previous first-generation social enterprises for their lack of a business model that satisfies both social and fiscal values. He points out that previous social enterprises were mainly small shops such as ice-cream parlors, cafés and restaurants which were not and will not be successful. This is because most social enterprises are small-scale, with annual sales of only around 200 thousand US\$, and so do not provide much employment, and also because they cannot cover additional costs related to training and management, as well as costs incurred in training and employing people from vulnerable classes. He argues that in order to maintain sustainability while covering all the costs of training and consulting, annual sales should be at least 100 million dollars. He suggests two alternatives for maintaining sustainability. One is to increase the size of a social enterprise to cover direct and indirect costs, and the other is to acknowledge that most social enterprises cannot in reality create enough profits on their 
own, and should therefore develop a stable and continuous funding source to compensate for losses.

Meanwhile, in line with the viewpoint arguing for the development of a new business model, according to the Johns Hopkins Survey the sustainability of a social economy organization depends on its economic sustainability, and thus securing stable finances is critical. Survey results show that, of the income generation activities undertaken by social economy organizations, 53 percent came from their income, 35 percent from government support, and 12 percent from donations [7]. The authors argue that since the relative importance of financial sources differs according to the different situations applying in different countries, individual countries should decide which financial source to focus on.

The third view focuses on the role and background of managers of a social enterprise. The OECD research report written by Noya and Lecamp [1] points out that in order to maintain the sustainability of social enterprises the role of social enterprise practitioners is important. The report argues that the founder of a social enterprise has an important role, and that this characteristics is especially important. Generally, the founder of a social enterprise participates in management in the early stages of the enterprise, and for this reason the founder's career and character affects the enterprise's success. Managers of social enterprises need management skills, and through using these should ensure the entrepreneurial survivability of their enterprise. Also, managers need to have a societal mindset in order to accomplish the social goals of the enterprise. In order to sufficiently secure these two aspects (i.e., business and social excellences), a manager should have professional experience and education, experience in working for a private enterprise, training, and so on. In this connection Noya and Lecamp [1] present results from research investigating the management of social enterprises in France.

Table 1. Educational Backgrounds of Entrepreneurs of Social Enterprises in France

\begin{tabular}{|c|c|c|c|}
\hline Initial state of career & Number & $\%$ & Continuous education \\
\hline $\begin{array}{l}\text { Special education, community work, social business, } \\
\text { counseling, psychology, job training }\end{array}$ & 60 & 38.5 & 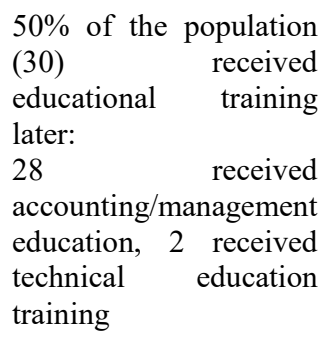 \\
\hline $\begin{array}{l}\text { Commerce, management, economics, finances, } \\
\text { accounting }\end{array}$ & 35 & 23 & $\begin{array}{l}14 \% \text { of the population } \\
(5) \text { received education } \\
\text { training later: } \\
4 \text { received social } \\
\text { business education, } 1 \\
\text { received technical } \\
\text { education }\end{array}$ \\
\hline $\begin{array}{l}\text { Technical qualification, physical labor (carpentry, } \\
\text { electricity, civil engineering) }\end{array}$ & 44 & 29 & $\begin{array}{l}45 \% \text { of the population } \\
\text { (20) received education } \\
\text { training: } 7 \text { received } \\
\text { social } \\
\text { education, } 13 \text { received } \\
\text { management/accounting } \\
\text { education training }\end{array}$ \\
\hline $\begin{array}{l}\text { Others (architecture, languages, human studies, } \\
\text { secretarial work, legal work) }\end{array}$ & 14 & 9.5 & \\
\hline Total & 153 & 100 & $55(36 \%)$ \\
\hline
\end{tabular}

Source: Noya and Lecamp (1999: 15). 
Table 1, shows that the educational backgrounds of social enterprise managers vary, from special education, to social businesses, counseling, and management and technical area work. Noya and Lecamp point that in order for social enterprise managers to make their enterprises successful they should be open to expert services and information, and thus these conditions have as much importance as the securing of finance or market sales conditions [1]. In this connection, local government in the Walloon area of Belgium, understanding the importance of expertise technology in social enterprise management, provides specialized academic degrees as well as training modules for social entrepreneurs. In France, a number of colleges and high-level educational institutions are constructing courses for future social entrepreneurs. In particular, they are expanding opportunities for entrepreneurs to receive professional consulting in order to increase their knowledge of both social and managerial aspects. In Italy, the importance of educational training and information provision for social entrepreneurs is acknowledged, and so the Government promotes networking with close supporting agencies. One example is provided by Imprenditorialità Giovanile (IG), a national institute for young social entrepreneurs which supports cooperation with agencies in the third sector and provides education on necessary management knowledge and networking. In east London, England, there are a number of schools for social entrepreneurs that provide professional education consultancy to young people especially. On account of such cases throughout the world, one can assume that the influence that social enterprise managers have on the success of the enterprise itself is very large, and that it is necessary to assist these entrepreneurs with various kinds of education and training, consultancy, and networking.

In line with the emphasis on the importance of social enterprise managers, Wippen and Cochrane [8] classified the opinions of other researchers [9-12] about the conditions for the sustainability of social enterprises according to six criteria: processes and structures, human resources, finance, governance, performance measurements, and market perception. Their findings imply that although all conditions are of importance, human resources are especially important, and so a social enterprise manager should possess both social values and entrepreneurial experience.

Researchers in Korea also propose similar conditions for sustainability. For instance, Jang et. al., [13] present CEO competence, employee competence, social entrepreneur course taking, management structure, accounting system, social enterprise authentication results, and social enterprise authentication acceptance as key conditions for the sustainability of social enterprises. The variables here are more specifically divided. In particular, while this research includes management structure and accounting systems as factors influencing the sustainability of social enterprises, it also stresses personal characteristics such as CEO leadership and educational course taking, and thus its findings can be seen as largely similar to those presented in recent OECD research. Meanwhile, Choi [14] and Nam [15] state that the CEO's social entrepreneurial spirit, background and management skills are important conditions for the sustainability of social enterprises. They emphasize the fact that the background, management skills and social mindset of a CEO of a social enterprise are as important as the supporting institutional conditions. A more thorough examination of conditions of social entrepreneurs shows that previous experiences of profit-making businesses, experience in receiving professional consultations while managing a social enterprise, and experience of professional education after managing a social enterprise may also be included.

The fourth view focuses on social enterprise networking. Some scholars [14-16] emphasize the importance of networks as a supportive structure for social enterprises. Basically, multi-stakeholder governance is important, and under this governance structure the networks between various supporting agencies are also important. In this connection, when the Office of the Third Sector (OTS) in the UK planned strategies to foster social enterprises, of all its strategies, the need to provide requisite information and consultation to social entrepreneurs through adequate networks was strongly emphasized [17]. 
In one case of related research, Choi [18] mentions that environmental aspects, such as the variety and the safety of resources and network formations, should also be considered as important factors influencing the sustainability of social enterprises. Moreover, Song [19] identifies a restructuring of political and economic networks, gaining the trust of the local society, and reciprocity with the local society as factors. Meanwhile, Park [20] and Kim [21] conducted a status analysis on social economy organizations within the Chungcheongbuk-do province area, and concluded that participation in various local networks relating to social enterprises strongly affects the success of an enterprise. A more regional approach taking into account the situation of Korea may include the utilization of social economy networks within local areas or social-economy-supporting agencies under the Ministry of Labor.

A comprehensive understanding of the researches mentioned above tells us that the conditions that affect the sustainability of social enterprises are: supportive measures at an institutional level, development of a new business model to secure finances, the characteristics and roles of social entrepreneurs, and social enterprise networks. The first two of these conditions call for long-term tasks and the latter two for short-term tasks which can be accomplished via short-term effort. This research focuses on short-term tasks that can be resolved locally in a short period rather than on long-term tasks. Summarizing the sustainability conditions for a social enterprise on a short term view, as seen from the above, we can identify: the experience of a social entrepreneur in a profitmaking business; experience of receiving professional consulting subsequent to management of a social enterprise; participation in a social economy network; completion of professional management education subsequent to management of a social enterprise; and use of social-enterprise-supporting institutions.

\subsection{Selection of Research Questions}

In this research, the conditions required to enhance the sustainability of social enterprises will be more focused toward short-term than toward long-term tasks. Shortterm tasks include the social entrepreneur's previous experience in participating in profitmaking business activities, receipt of professional consulting targeted on social enterprises, participating in social economy networks, acquiring personal professional education for social enterprises, and using local social enterprise support organizations. In consideration of such factors, this research proposes the following research questions:

1. To which category do social enterprises that are highly sustainable belong?

2. What combinations of conditions affect the sustainability of social enterprises?

3. What policy decisions can be made to improve the sustainability of social enterprises?

\section{Research Design}

\subsection{Methodologies}

In order to categorize social enterprise types and derive a combination of conditions that affect sustainability, a Qualitative Comparative Analysis (QCA) will be used in this research. QCA is a comparative technique that uses a small number of cases (5-55) to explain a large social phenomenon in a concise manner [22]. While QCA does not provide the statistical results required for an overall generalization, it is a useful method that permits a simple grouping of difficult and complicated cases according to their characteristics [23]. QCA was developed into a social science methodology by Ragin [24], and has not been widely known up until now. The main objective of this method is to provide concise interpretations of the causal patterns proposed by the cases being examined. This method aims to identify the various causal conditions or combinations of 
condition variables that affect the results. That is, it starts from the assumption that one outcome does not have one set of variables, but in fact might possess several sets of different conditions [25]. Another characteristic of this methodology is the use of set theory, Boolean algebra, composition of a truth table, and a concise approach toward the analysis data [26]. This QCA method is of three broad types: crisp set QCA (CSQCA), fuzzy set QCA (FSQCA), and multi-value QCA (MVQCA). This research will use CSQCA, in which values are converted into 0 and 1 by comparing the original value with a specific threshold. Investigating the main subject of research, that is, the sustainability of social enterprises and the individuals that affect it, elicits mainly yes or no results, which in this case are easier to comprehend using 0 and 1.1 Accordingly, the CSQCA program and TOSMANA program will be used in this research

\subsection{Variables}

The dependent variable included in this research is the sustainability of social enterprises, and the independent variables are five in total: experience of social entrepreneurs in profit-making businesses; participation in local social networks; experience in receiving professional consultation; the manager's completion of professional education; and use of local social-enterprise-support institutions. The contents of these variables and the methods used to measure and process them are shown in Table 2.

Table 2. Contents of Variables and Methods of Measurement

\begin{tabular}{|c|c|c|c|c|}
\hline $\begin{array}{l}\text { Variable } \\
\text { abbreviation }\end{array}$ & Variable name & Operationalization & $\begin{array}{l}\text { Intersecting point } \\
\text { (range) }\end{array}$ & Note \\
\hline buse & Business experience & $\begin{array}{l}\text { Whether one has participated } \\
\text { in profit-making businesses } \\
\text { prior to becoming CEO of a } \\
\text { social enterprise }\end{array}$ & $\begin{array}{l}\text { More than } 1 \\
\text { year: } 1 \\
\text { less than } 1 \text { year } \\
\text { or none: } 0\end{array}$ & \\
\hline netc & $\begin{array}{l}\text { Participation in local } \\
\text { social economy networks }\end{array}$ & $\begin{array}{l}\text { Participation in Chungbuk } \\
\text { social enterprise council }\end{array}$ & $\begin{array}{l}\text { Members or } \\
\text { board members: } \\
1 \\
\text { Non-members: } 0\end{array}$ & \\
\hline cons & $\begin{array}{l}\text { Experience in receiving } \\
\text { professional consultancy }\end{array}$ & $\begin{array}{l}\text { Experience in receiving } \\
\text { professional consultancy } \\
\text { since management }\end{array}$ & $\begin{array}{l}\text { Has consulting } \\
\text { experience: } 1 \\
\text { Else: } 0\end{array}$ & $\begin{array}{l}\text { Restricted } \\
\text { optional } \\
\text { consultancy } \\
\text { (mandatory } \\
\text { consultancy } \\
\text { excluded) }\end{array}$ \\
\hline edue & $\begin{array}{l}\text { Manager's experience of } \\
\text { professional education } \\
\text { completion }\end{array}$ & $\begin{array}{l}\text { Experience of the manager } \\
\text { completing professional } \\
\text { education since management }\end{array}$ & $\begin{array}{l}\text { Has experience } \\
\text { of completion: } 1 \\
\text { Other: } 0\end{array}$ & $\begin{array}{l}\text { Restricted } \\
\text { completion } \\
\text { professional } \\
\text { education }\end{array}$ \\
\hline intc & $\begin{array}{l}\text { Usage of medium } \\
\text { support institutions }\end{array}$ & $\begin{array}{l}\text { Usage of the Chungbuk } \\
\text { social economy center }\end{array}$ & $\begin{array}{l}\text { Strong exchange } \\
\text { of information } \\
\text { with rocial } \\
\text { economy centers: } \\
1 \\
\text { Other: } 0\end{array}$ & $\begin{array}{l}\text { Referring to the } \\
\text { self-evaluation } \\
\text { report from the } \\
\text { Chungbuk social } \\
\text { economy center }\end{array}$ \\
\hline sust & Sustainability & $\begin{array}{l}\text { Sustainability for more than } \\
3 \text { years }\end{array}$ & $\begin{array}{l}\text { If number of } \\
\text { employees } \\
\text { increased more } \\
\text { than } 10 \% \text { during } \\
\text { the last } 3 \text { years: } 1 \\
\text { Other: } 0\end{array}$ & $\begin{array}{l}\text { Referring to self- } \\
\text { evaluation reports }\end{array}$ \\
\hline
\end{tabular}

1 For details regarding this method see Choi (2013). 


\subsection{Research Targets}

The spatial target of this research is restricted to social enterprises located in the Chungbuk province area. Of the 1251 social enterprises operating throughout Korea as of December 31, 2014, 64 are situated in Chungbuk province. However, when considering the sustainability of social enterprises, the target must be restricted to enterprises that have been managed for three or more years. Therefore, this research targets enterprises established before 2011 and excludes the 20 enterprises established afterwards. The year of establishment of the social enterprises in Chungbuk province selected for research is shown in Table 3.

\section{Table 3. Social Enterprises Sorted by Year of Foundation (Chungbuk Province)}

\begin{tabular}{cccccccc}
\hline Division & 1995 & 1998 & 2002 & 2003 & 2004 & 2005 & 2006 \\
\hline Numbers & 1 & 1 & 1 & 5 & 2 & 1 & 1 \\
\hline \multicolumn{1}{c}{2007} & 2008 & 2009 & 2010 & 2011 & 2012 & Total \\
\hline 5 & 7 & 3 & 5 & 11 & 1 & 44 \\
\hline
\end{tabular}

Note. Although the Social Enterprise Promotion Act was enacted in 2007, enterprises that were established earlier and later received certification are also included.

Meanwhile, Table 4, shows the locations of social enterprises in the Chungbuk area. Cheongju City has the most enterprises, accounting for around 60 percent of all enterprises, while the other enterprises are spread throughout a number of different locations.

\section{Table 4. Social Enterprises Categorized by Location (Chungbuk Province)}

\begin{tabular}{|c|c|c|c|c|c|c|c|c|c|c|}
\hline Division & $\begin{array}{l}\text { Goesa } \\
\text { n-gun }\end{array}$ & $\begin{array}{l}\text { Danyang } \\
\text {-gun }\end{array}$ & $\begin{array}{l}\text { Yeongdong } \\
\text {-gun }\end{array}$ & $\begin{array}{c}\text { g Okcheon } \\
\text {-gun }\end{array}$ & $\begin{array}{l}\text { Eumseong- } \\
\text { gun }\end{array}$ & $\begin{array}{l}\text { s- Jecheon- } \\
\text { si }\end{array}$ & $\begin{array}{l}\text { - Jincheon- } \\
\text { gun }\end{array}$ & ${ }^{1-}$ Cheongju-si & i Chungiu-si & i Total \\
\hline Numbers & 3 & 2 & 2 & 1 & 1 & 3 & 2 & 27 & 3 & 44 \\
\hline
\end{tabular}

Note: gun means rural district.

Social enterprises are categorized into groups according to their purpose as determined at the time of their establishment. As Table 5, shows, 29 enterprises come under the category 'job provision' and eight under 'mixed', while 'service provision' is small in number, with only two enterprises.

Table 5. Social Enterprises Categorized by Type (Chungbuk Provision)

\begin{tabular}{cccccc}
\hline Division & Social service provision & Job provision & Mixed & Other & Total \\
\hline Number & 2 & 29 & 8 & 5 & 44 \\
\hline
\end{tabular}

\section{Analysis Results}

\subsection{General State of Research Targets}

The social enterprises that formed the subject of this research were all established before 2011. This is because, considering the aspect of sustainability, a sustainable enterprise needed to have been managed for at least three years. There are 64 social enterprises in Chungbuk province, and those which had been under operation for over 
three years prior to December 2014 (i.e., enterprises established before 2011) are shown in Table 6.

Table 6. Characteristics of Variables in Targeted Social Enterprises

\begin{tabular}{|c|c|c|c|}
\hline Division & Positive or strong : 1 & Negative or weak: 0 & Note \\
\hline Business experience & $14(31.8 \%$ & $30(68.2 \%)$ & Survey \\
\hline $\begin{array}{l}\text { Participation in local } \\
\text { social economy networks }\end{array}$ & $37(84.1 \%)$ & $7(15.9 \%)$ & $\begin{array}{ll}\text { Self-evaluation } & \text { report } \\
\text { from Chungbuk } & \text { social } \\
\text { economy center } & \end{array}$ \\
\hline $\begin{array}{l}\text { Professional consultancy } \\
\text { experience }\end{array}$ & $9(20.5 \%)$ & $35(79.5 \%)$ & Survey \\
\hline $\begin{array}{l}\text { Manager's experience in } \\
\text { completion of } \\
\text { professional education }\end{array}$ & $24(54.5 \%)$ & $20(45.5 \%)$ & Survey \\
\hline $\begin{array}{l}\text { Use of medium support } \\
\text { institutions }\end{array}$ & $15(34.1 \%)$ & $29(65.9 \%)$ & $\begin{array}{ll}\text { Self-evaluation } & \text { report } \\
\text { from Chungbuk } & \text { social } \\
\text { economy center } & \end{array}$ \\
\hline Sustainability & $28(63.6 \%)$ & $16(36.4 \%)$ & $\begin{array}{l}2014 \text { performance report } \\
\text { of Chungbuk social } \\
\text { economy center }\end{array}$ \\
\hline
\end{tabular}

As Table 6, shows, 31.8 percent of the managers of social enterprises had experience in profit-making businesses of more than one year, and 68.2 percent were inexperienced. Most of the social entrepreneurs had no experience of profit-making areas. As for experience in local social economy network participation, 84.1 percent of all social entrepreneurs participated in the Chungbuk social enterprise council as members. As regards social entrepreneurs receiving professional consulting that was not compulsorily provided but required by the managers themselves, 79.5 percent replied that they had no such experience. Meanwhile, in terms of business use of the Chungbuk social economy center (a consignment organization of the Ministry of Employment and Labor), 65.9 percent of managers recorded low usage. Looking at sustainability as a dependent variable reveals that 64 percent saw an increase rate of higher than 10 percent in the number of employees.

\subsection{Analysis Results of TruthTtable}

First: assigning the numbers 0 or 1 to 44 social enterprises using variable intersection points gives the result shown in Table 7. 
Table 7. Results of Applying Intersecting Points to Variables

\begin{tabular}{|c|c|c|c|c|c|c|}
\hline Company name & sust (sustainability) & $\begin{array}{l}\text { buse (experience in } \\
\text { profit-making } \\
\text { business) }\end{array}$ & $\begin{array}{l}\text { ncons } \\
\text { (consultancy } \\
\text { experience) }\end{array}$ & $\begin{array}{l}\text { netc } \\
\text { (networking) }\end{array}$ & $\begin{array}{l}\text { edue } \\
\text { (professional } \\
\text { education } \\
\text { experience) }\end{array}$ & $\begin{array}{l}\text { intc (participation } \\
\text { in middle support } \\
\text { institution) }\end{array}$ \\
\hline e1 & 0 & 0 & 0 & 1 & 0 & 0 \\
\hline e2 & 1 & 0 & 1 & 1 & 1 & 1 \\
\hline e3 & 1 & 0 & 1 & 1 & 1 & 1 \\
\hline e4 & 0 & 0 & 1 & 1 & 1 & 1 \\
\hline e5 & 0 & 0 & 0 & 1 & 1 & 1 \\
\hline e6 & 0 & 1 & 0 & 1 & 1 & 0 \\
\hline e7 & 0 & 0 & 0 & 1 & 1 & 1 \\
\hline e8 & 0 & 0 & 0 & 0 & 0 & 0 \\
\hline e9 & 1 & 0 & 1 & 1 & 1 & 1 \\
\hline $\mathrm{e} 10$ & 1 & 0 & 0 & 1 & 0 & 0 \\
\hline e11 & 1 & 0 & 0 & 0 & 0 & 0 \\
\hline $\mathrm{e} 12$ & 1 & 0 & 0 & 1 & 1 & 0 \\
\hline e13 & 1 & 1 & 0 & 1 & 1 & 1 \\
\hline e14 & 1 & 0 & 1 & 1 & 0 & 0 \\
\hline e15 & 0 & 0 & 0 & 1 & 0 & 0 \\
\hline e16 & 0 & 1 & 1 & 1 & 1 & 0 \\
\hline e17 & 1 & 0 & 0 & 1 & 0 & 0 \\
\hline e18 & 1 & 0 & 0 & 0 & 0 & 0 \\
\hline e19 & 1 & 1 & 0 & 1 & 1 & 1 \\
\hline e20 & 0 & 0 & 0 & 0 & 0 & 0 \\
\hline e21 & 1 & 0 & 0 & 1 & 1 & 1 \\
\hline $\mathrm{e} 22$ & 0 & 0 & 0 & 1 & 1 & 0 \\
\hline e23 & 1 & 1 & 0 & 1 & 1 & 0 \\
\hline e24 & 1 & 0 & 0 & 1 & 0 & 0 \\
\hline e25 & 1 & 0 & 0 & 1 & 0 & 0 \\
\hline e26 & 1 & 1 & 0 & 1 & 1 & 1 \\
\hline e27 & 0 & 0 & 0 & 1 & 1 & 0 \\
\hline e28 & 0 & 1 & 0 & 1 & 0 & 0 \\
\hline e29 & 1 & 1 & 1 & 1 & 1 & 1 \\
\hline e30 & 1 & 0 & 0 & 0 & 1 & 0 \\
\hline e31 & 1 & 0 & 0 & 1 & 1 & 1 \\
\hline e 32 & 1 & 0 & 0 & 1 & 0 & 0 \\
\hline e33 & 1 & 0 & 0 & 1 & 0 & 0 \\
\hline e34 & 0 & 0 & 0 & 1 & 0 & 0 \\
\hline e35 & 1 & 1 & 0 & 1 & 1 & 0 \\
\hline e36 & 0 & 1 & 0 & 1 & 1 & 1 \\
\hline e37 & 1 & 0 & 0 & 1 & 0 & 0 \\
\hline e38 & 1 & 1 & 1 & 1 & 0 & 0 \\
\hline e39 & 1 & 1 & 0 & 0 & 0 & 0 \\
\hline e40 & 1 & 0 & 0 & 0 & 0 & 0 \\
\hline e41 & 0 & 1 & 0 & 1 & 1 & 1 \\
\hline e42 & 1 & 0 & 0 & 1 & 0 & 0 \\
\hline e43 & 1 & 1 & 1 & 1 & 1 & 1 \\
\hline e44 & 0 & 0 & 0 & 1 & 1 & 0 \\
\hline
\end{tabular}

Note. The enterprises have been anonymized, and are shown by designations from e1 to e44. 
The results of using the CSQCA program and TOSMANA program on this data in the form of a truth table analysis are shown in Table 8. That is, the combinations of variables that affect the sustainability of social enterprises are made with 5 independent variables and 1 dependent variable. The value 1 stands for 'positive', such as being experienced or having a strong network, and 0 stands for 'negative', such as being unexperienced or having a weak network. When the dependent variable, that is, sustainability, is 1 , there are 5 possible configurations. That is, if the configuration belongs to one of these 5 configurations, then that social enterprise can be considered sustainable. There is a need to further condense these 5 configurations and derive major implicants. This approach has significance from a policy viewpoint since it seeks simplified core factors. In other words, for the policy decision maker needing to take necessary measures to enhance the sustainability of social enterprises, understanding the results of this approach can help to provide policy support by focusing on the prime implicants. These 5 configurations can be further condensed into 4 prime implicants, which have significance as sufficient conditions that lead to the dependent variable.

\section{Table 8. Analysis Results Regarding the Sustainability of Social Enterprises}

\section{Truth Table:}

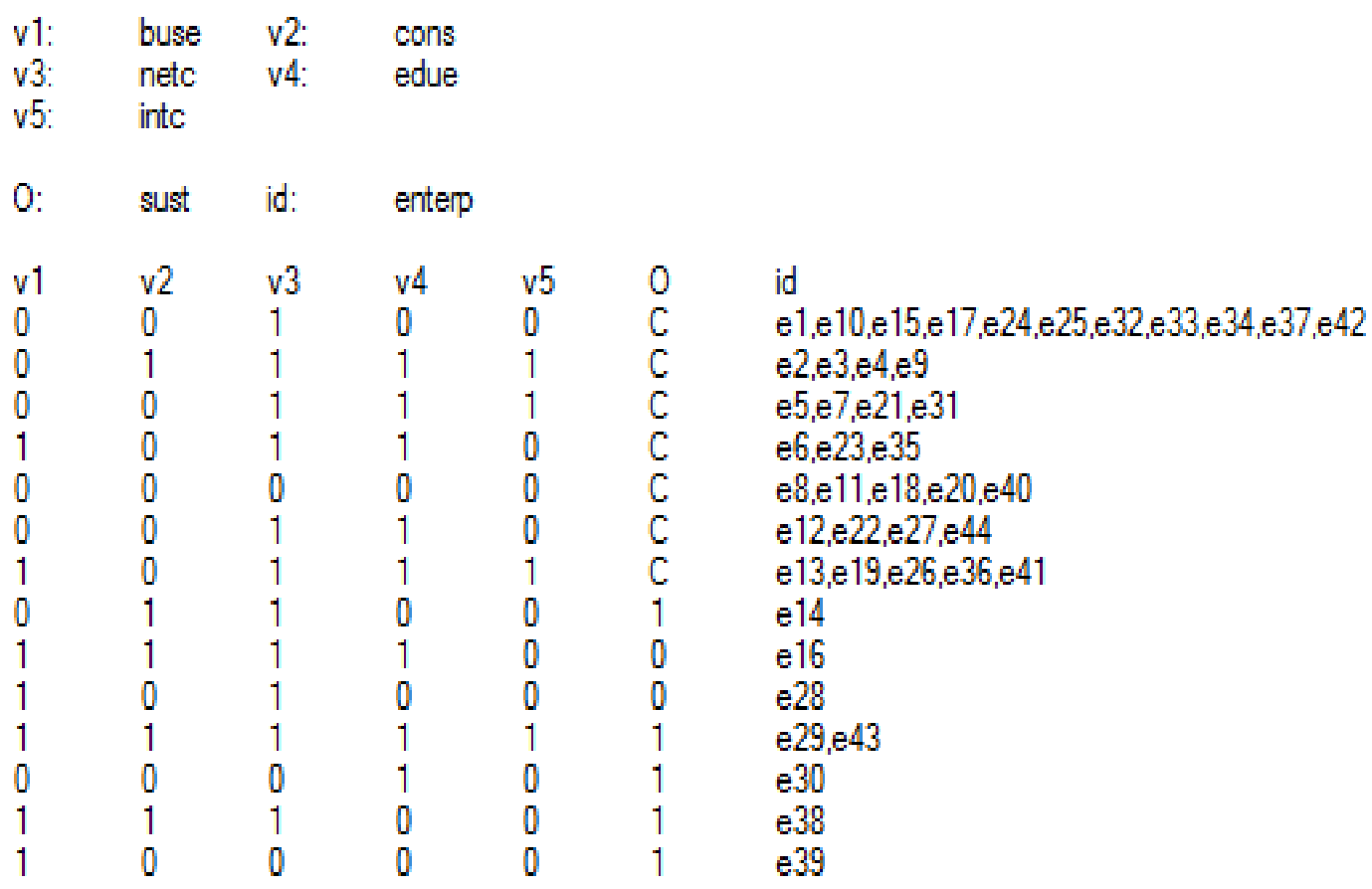

Note. In the set theory, * stands for 'AND' and + stands for 'OR'.

A graphic description of the truth table analysis results is made by the TOSMANA program and is displayed below. In Figure 2, there are five configurations that have the value 1 as well as several configurations that have the value $C$, which stands for contradictory. 


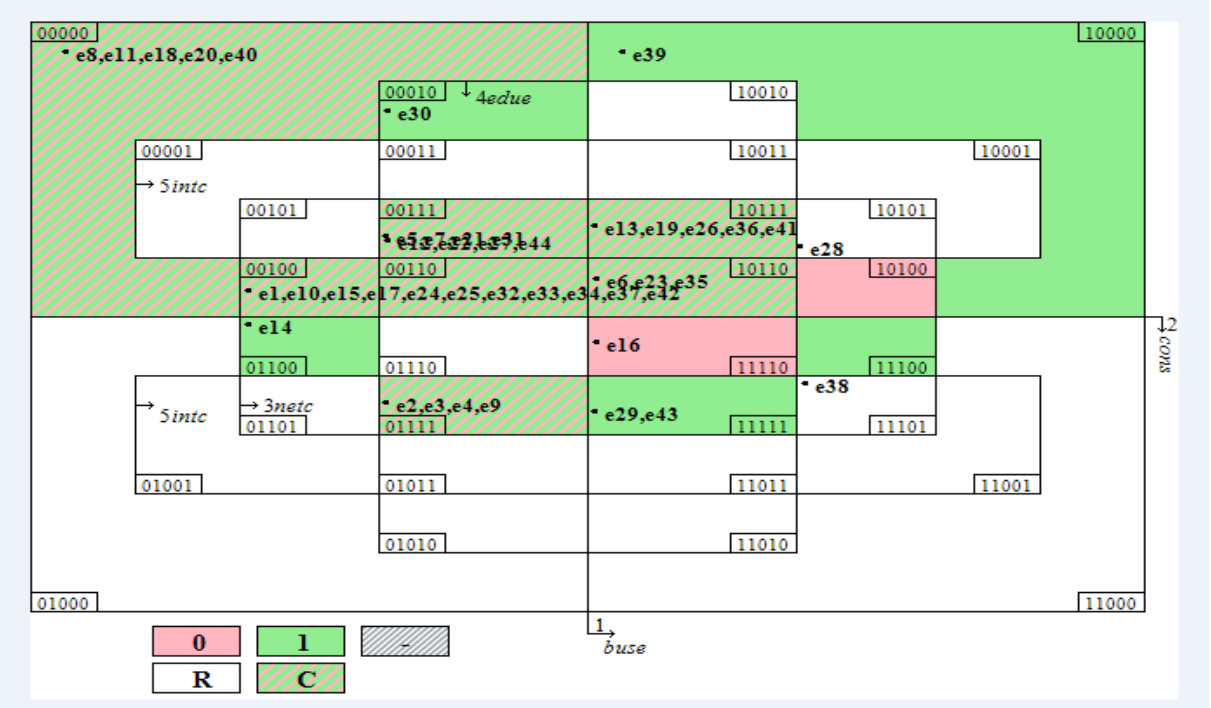

Figure 2. Venn Diagram Showing Analysis Results of the Truth Table

The Venn diagram above explains the logical relation between the conditions being applied to sustainability factors.. Each area is filled with slashes or colors and displays the various configurations that derive from the truth table analysis. These are created by the visualization tool in the TOSMANA program. Organizing the core factors that affect sustainability on the basis of the prime indicants of the truth table analysis provides the results shown in Table 9.

Table 9. Classification of Sustainability Types

\begin{tabular}{lll}
\hline Division & Relevant social enterprise & Note \\
\hline Type 1:CONS*NETC*edue*intc & e14, e38 & $\begin{array}{l}\text { Integration of two } \\
\text { types }\end{array}$ \\
Type 2:BUSE*CONS*NETC*EDUE*INTC & e29, e43 & \\
Type 3: buse*cons*netc*EDUE*intc & e30 & \\
Type 4: BUSE*cons*netc*edue*intc & e39 & \\
\hline
\end{tabular}

Note. Upper-case terms represent1; lower-case terms represent 0.

Five configurations of influence factors are created by the truth table analysis, while the implicants are reduced to 4 configurations. Type 1, which is a configuration of variables found in enterprises e14 and e38, shows that if the condition CONS*NETC*edue*intc is made with 4 out of the 5 independent variables, regardless of the value of the business experience of the manager, that is of the variable having the value 'buse' or 'BUSE', the possibility of sustainability can rise. As Table 9, shows, there are in total 4 types of sufficient conditions that can bring sustainability to a social enterprise. Type 1 relates to enterprises whose manager has received no consultations, does well in social economy networking, has no experience of receiving professional education, and does not participate very much in middle support organizations. Two enterprises, e14 and e38, belong to this category. Type 2 relates to enterprises whose manager has previous experience in profit-making businesses, has received consultations, has a strong social economy network, has received professional education, and actively participates in middle support organizations. Enterprises e 29 and e 43 belong to this category. Type 3 enterprises are run by managers who have limited experience in business management, consultancy and social economy networking, but have received professional education 
and have a low participation rate in middle support organizations. One enterprise, e30, belongs to this group. Last of all, Type 4 enterprise managers have business experience, limited consulting experience, a low level of networking, limited experience in completing professional education, and also a low level of participation in middle support organizations. One enterprise, e39, belongs to this type.

\subsection{Discussion: Implications}

As the above shows, in theory several factors can influence the sustainability of social enterprises. Of these, this research selected five as independent variables and tried to observe the combinations of conditions that affect sustainability. In order to analyze data involving a small number of cases and discrete independent variable values, a QCA analysis method was adopted. The results show that there are five conditions for the factors that influence the sustainability of social enterprises. However, the results of a prime implicants analysis led us to categorize these into four types, as displayed in the set equations below. The four combinations of variables are:

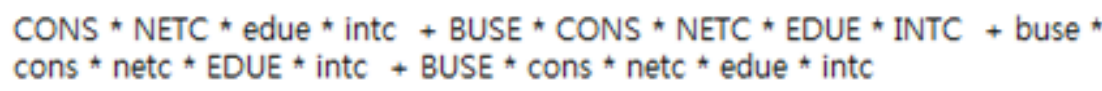

Here, * stands for 'AND' and + stands for 'OR'. Therefore, if the conditions of a social enterprise satisfy the CONS*NETC*edue*intc condition, the USE*CONS*NETC*EDUE*INTC condition, the buse*cons*netc*EDUE*intc condition or the BUSE*cons*netc*edue*intc condition, it can be assumed that this enterprise may be highly sustainable. In consideration of this, the results imply that enterprises with poor sustainability can observe their current situation and try to bring about combinations which ensure sustainability and are similar to their own, or which can be relatively easily accomplished and thus enhance sustainability. By using these results as background information when central or local government plans policies for improving the sustainability of social enterprises, policy makers can be provided with significant information on selecting models by considering the situations of individual enterprises. Also, social enterprises will be able to consider models that have the largest resemblance to themselves and thus try to enhance their sustainability.

\section{Conclusion}

This research applied the QCA method to a social enterprise sector. This method is helpful in making comparisons on small cases, but is not widely used in social sciences, especially in the field of public administration. The role of social enterprises is becoming more and more important both in Korea and throughout the world, and so enhancing their sustainability has become an important issue for both policy decision makers and social enterprise managers. However, this research lacks sufficient cases for investigation, and it is difficult to use quantitative methods such as regression analysis. However, considering that, in the actual policy scene, output is produced according to the combination of various variable conditions, the QCA method can be widely applied. Analyzing the combinations of conditions that affect the sustainability of social enterprises located in Chungbuk area only led to five types of combinations being found, and these could be further condensed into four types. The information provided in this research can be used by future local authorities or social entrepreneurs to gain understanding of the characteristics of the different types of sustainable social enterprises and improve the sustainability of such enterprises in the Chungbuk area. 


\section{Acknowledgments}

This work was supported by the National Foundation of Research Grant funded by the Korean Government (NRF-2015S1A5B8046954).

\section{References}

[1] A. Noya and C. Lecamp, "Social Enterprises", Paris: OECD, (1999).

[2] A. Noya and E. Clarence, "The Social Economy Building Inclusive Economies", Paris: OECD, (2007).

[3] Salamon, L., Sokolowski, W. and List, R.: Global Civil Society: An overview, Johns Hopkins Center for Civil Society Studies, www.jhu.edu/-ccss, (2003).

[4] C. Borzaga and E. Tortia, "Social economy organisations in theory of the firm. In Noya, A. and Clarence, E. (eds), The Social Economy, Paris: OECD, (2007).

[5] K. H. Miceva, "A supportive financing framework for social economy organisations", In Noya, A. and Clarence, E. (eds), The Social Economy, Paris: OECD, (2007).

[6] D. Rutzen, M. Durham and D. Moore, "Overview of NPO Legislation in Central and East Europe", www.icnl.org, (2004).

[7] J. Schorr, "Social Enterprise 2.0", Stanford Social Innovation Review, vol. 4, (2006), pp. 122-13.

[8] J. Wippen and J. Cochrane, "Social enterprises in tourism: an exploratory study of operational models and success factors", Journal of Sustainable Tourism, vol. 20, no. 3, (2012), pp. 497-511.

[9] J. Austin, H. Stevenson and J. W. Skillern, "Social and commercial entrepreneurship: same, different, or both", Entrepreneurship Theory and Practice, (2006) January, pp. 1-22.

[10] M. London and R. G. Morfopoulos, "Social Entrepreneurship: How to start successful corporate social responsibility and community-based initiatives for advocacy and change", London: Routledge, (2010).

[11] K. Lynch and J. Walls, "Mission, Inc.: The practitioner's guide to social enterprise", San Francisco, CA: Berrett-Koehler, (2009).

[12] I. C. Rada and L. D. Magdoiu, "Managers and engineer economists in the development of the social economy", Journal of Electrical and Electronics Engineering, vol. 1, no. 1, (2013).

[13] Y. R. Jang, J. H. Hong and J. H. Cha, "Performance of social enterprises", Accounting Information Review, vol. 20, no. 2, (2012), pp. 175-207.

[14] Y. C. Choi, "Factors affecting success of social enterprises", Korean Comparative Government Studies, vol. 17, no. 1, (2013), pp. 43-60.

[15] M. O. Nam, "Sustainability in integrated type of social enterprise", Social Enterprise and Policy Studies, vol. 3, no. 2, (2014), pp. 71-102.

[16] S. Y. Lee and K. S. Jung, "Community business: future directions", Korean Comparative Government Studies, vol. 15, no. 2, (2011), pp. 221-52.

[17] A. Noya, "The Changing Boundaries of Social Enterprises", Paris: OECD, (2009).

[18] J. S. Choi, "Social Entrepreneurship and Social Enterprise", PhD thesis, Seoul City University, Korea, (2012).

[19] T. S. Song, "Sustainable development for social enterprises", Korean Policy Studies Review, vol. 12, no. 4, (2012), pp. 309-24.

[20] D. H. Park, "Impacts of Social Economy Organisations on Economic Activities", MA thesis, Chungbuk National University, Korea, (2015).

[21] S. Y. Kim, "Future directions for sustainability for social enterprise", Social Enterprise and Policy Studies, vol. 2, no. 2, (2013), pp. 77-96.

[22] M. P. Vink and O. V. Vliet, "Not quite crisp, not yet fuzzy?", Assessing the potentials and pitfalls of multi-value QCA, Field Methods, vol. 21, no. 3, (2009), pp. 265-89.

[23] L. Luck, D. Jackson and K. Usher, "Case study: a bridge across the paradigms", Nursing Inquiry, vol. 13, no. 2, (2006), pp. 103-9.

[24] C. Ragin, "The Comparative Method: Moving Beyond Qualitative and Quantitative Strategies", Berkeley, CA: University of California Press, (1987).

[25] C. Wagner and C. Q. Schneider, "Qualitative comparative analysis (QCA) and fuzzy-sets: agenda for a research approach and a data analysis technique", Comparative Sociology, vol. 9, no. 3, (2010), pp. 37696.

[26] F. Donnelly and R. Wiechula, "An example of qualitative comparative analysis in nursing research", Nurse Researcher, vol. 20, no. 6, (2013), pp. 6-11. 
International Journal of $u$ - and e- Service, Science and Technology Vol.9, No. 10 (2016) 